\title{
TEXTUAL NOTES ON PALLADIUS’ OPUS AGRICULTURAE
}

\section{${\underline{1.13 .2^{1)}}}^{1)}$}

dehinc primo inpensa pumicae inducemus et trulla aequabimus, ut inter se cannarum membra constringat. ${ }^{2)}$

pumicae scripsit Rodgers : pumica DKJLS : punica $M$ : pumicea $G$, edd. | inducemus $\varsigma$ : indu*emus $G$ : induemus $D K J L S M \mid$ aequauimus $D K^{1} J L$

In the course of giving instructions for the construction of roofing and ceilings in farm buildings, Palladius completes his description of wattling, before turning to the application of the daub. ${ }^{3)}$ Rodgers' recension of the text may be rendered thus: 'then we shall first coat [the wattle] with a daub of pumice and shall level it with a trowel'. The choice between inducemus and induemus is straightforward: inducemus, a correction attributed by Rodgers to MSS dating from the twelfth century, ${ }^{4)}$ is correct (v. OLD s.v. induco 16b). The corruption of induco to various forms of induo occurs several times in the uetustiores (for example, 1.37.7, inducta testaceo et albario opere, where the MSS derived from the archetype $\omega$ have induta; 4.10.8, si inducantur argilla, where they have induantur). ${ }^{5)}$ As to the type of inpensa which was applied, the majority of the manuscripts have pumica, either an orthographical variant of punicus -a -um (TLL 10.2.2637.17) and thus having little sense here, or the ablative of pumica -ae in apposition to inpensa, which seems extremely unlikely:

\footnotetext{
1) I use the Teubner text and apparatus of Rodgers 1975a as the basis for these notes.

${ }^{2)}$ In Rodgers' edition there is a typographical error here which reads inducem uset.

3) The translation of Fitch $(2013,272)$ provides a helpfully annotated cross-section of the construction to be undertaken.

4) Rodgers 1975b, 83 for a list of recc. reading inducemus here.

5) The anonymous reader has drawn my attention to Moure Casas' 1980 edition which reads induemus (1.13.2) and induta (1.37.7), though no reason is offered for favouring these readings, nor does Corsetti (1985), 298 offer any rationale for his satisfaction with them. At 1.13.2, with no variant readings offered in the apparatus criticus, Martin (1976) also reads induemus, though he favours inducta at 1.37.7. No suitable comparanda for induo referring to 'covering', 'spreading', or 'smearing with' a substance are offered by TLL (7.1.1234.74-1235.31) s.v. induo, whilst induco is used by Palladius precisely to mean 'cover', 'spread', or 'smear with' in a number of instances where the manuscript tradition is unanimous, for example: 1.9.4, 1.11, 1.34.5, 4.10.29.
} 
Rodgers thus prints inpensa pumicae with 'pumice' in the genitive. There are very few attestations of the noun pumica extant (TLL 10.2.2634.16-20), not that this alone should be problematic, but in Rodgers' own words, there are 'no examples' known to us of inpensa meaning mortar which take a substantival genitive of material, as his recension requires. [NT. 6] In support of his text, he cites the MSS of the third- or fourth-century writer Cetius Faventinus on whom Palladius drew for his discussion of daubing, all of which read pumicae (pun-), though modern editors of Faventinus' text have found the paradosis of $\S 21$ problematic for the very reason that there are no other instances known to us of inpensa followed by a substantival genitive of material: they thus emend to postea primo manu inducatur inpensa pumicea, <et> trullizetur, ut canna subligetur (21). In doing so, the Faventine editors cite the reading of the Palladian MS G, pumicea, from the passage in question: ${ }^{6)}$ both readings, then, cyclically rely on each other in their uncertainty, with neither being able to provide a definitive solution to the quandary. We must look elsewhere. There are instances of inpensa taking an adjective of material, once elsewhere in Palladius (1.39.5: et ita inpensam testaceam subter inducis), and a couple of times in Faventinus' work, also with testacea (18 and 19.2). In spite of the evidence that inpensa may be followed by an adjective of material, ${ }^{7)}$ Rodgers objects to the pumicea of G, printed by editors of Palladius since the Aldine edition, as he claims to have been unable to find any instances of the adjective pumiceus - $a$-um outside of poetry. There are, however, at least two prose usages extant, in the uariae of Cassiodorus (4.50.5), and in Scribonius Largus’ compositiones (34). ${ }^{8)}$ Not only, then, should we accept the emendation to pumicea $<e t>$ in the text of Faventinus, but it also

\footnotetext{
6) Cam 2001, 30, after Rose \& Müller-Strübing 1867, 304.

7) TLL 7.1.552.34-6.

8) TLL 10.2.2636.37 and 44. The text here is sound: the MSS of Cassiodorus offer only the orthographical variant puniceas and the nonsensical punices for the paradosis' pumiceas; and Scribonius' transmission only varies in orthography (again, puniceum for pumiceum).
} 
seems most likely that Palladius wrote dehinc primo inpensa pumicea inducemus et trulla aequabimus.

\section{$\underline{1.35 .10}$}

[iubent] tunc omnes paruulos aditus et reliqua spiramenta talparum diligenter adobrui; unum foramen, quod amplum est, reseruari, in cuius aditu nucem intus incensam sic poni.

adobrui $D K J L S$ : obrui $G$

Then [they suggest that] every last one of the moles' entrances, however small, is covered over, along with the remaining air-passages; one opening, which is wide, should remain unblocked, at the opening of which the nut is to be placed, with the fire inside it.

For (ad)obrui the Aldine editor printed obstrui, emending without good reason, given that either of the two transmitted readings is (broadly speaking) possible. That being said, G's obrui seems more likely to me to be the correct reading, predominantly because adobruo is almost exclusively used of plants or seeds being buried, whilst obruo has a much wider semantic range. Two instances are listed in TLL of adobruo being used to speak of burying things which do not pertain to plants (non de herbis, 1.792.83-6): one is this passage, where the manuscript tradition is divided over this word, and the other is a passage in Columella where the author describes how potsherds or shells may be buried so as to act as a base for planting seeds (tum testulae uel conchae quasi sedes singulis subiectae seminibus adobruuntur (11.3.31)). This latter instance seems to be describing a form of planting (or, at least, preparation for planting), and so the use of adobruo should not surprise. In the Palladius passage, it would be a straightforward attraction from either aditus in the preceding line, or aditu in the following line, which might have led to the corruption of obrui to adobrui, both of which are good Latin words and close in meaning; we 
should print obrui. ${ }^{9)}$

\section{$\underline{3.12 .2}$}

auferenda sunt lata, intorta, debilia, malis locis nata sarmenta. focalis etiam, qui inter duo brachia medius nascitur, debet abradi.

Shoots that are wide, twisted, feeble, or growing in the wrong place are to be removed. The focalis, which grows centrally between two branches of a vine, ought too to be rubbed away.

focalis, apparently a ö $\pi \alpha \xi \lambda \varepsilon \gamma o ́ \mu \varepsilon v o v$, is printed by Rodgers in his edition of the text where Schmitt had printed focaneus. The latter is used by Columella thrice (twice in 4.24.10, and 5.6.35) to mean 'a branch growing from the fork of a tree' (OLD s.v.): focaneus est, qui inter duo bracchia uelut in furca de medio nascitur (5.6.35). This is exactly the sense we require here. Rodgers' focalis appears in two manuscripts ( $\left.\mathrm{S}^{1} \mathrm{M}\right)$, whilst the others have focata (DPKJL); $\mathrm{S}^{2}$ in margine also has uel focata. focalis, apart from being the genitive singular of focale (an effeminate scarf of sorts) in classical Latin, is a very common mediaeval word, an adjective (relating to focus -i), which is also used substantivally to mean 'fuel' (DMLBS s.v. 3). focata does not mean anything, either in classical or mediaeval Latin, though it does appear rather Latinate. Palladius, who knew his Columella well, seems likely to have written focaneus. It would be very easy for a scribe, perhaps not so well-versed in his Columella, to misread focaneus as the much more common focalis, or the Latinatelooking focata, under the influence of having written malis or nata in the four words preceding the one in question. It seems quite clear that we should not print the nonsensical focalis as Rodgers does.

\section{$\underline{3.31 .1}$}

\footnotetext{
9) The anonymous reader has pointed out that diligenter obrui $(-\mathrm{v}-\mathrm{v} \mid-\mathrm{vv})$ also gives a better clausula than diligenter adobrui $(-\mathrm{v}-\mathrm{v} \mid \mathrm{v}-\mathrm{vv})$.
} 
myrti bacas maturas in umbra siccatas et postea tusas, uncias octo mittis in linteo et suspendis in uino et uas cooperies ac †linabis $\dagger$, et cum plurimis diebus sic fuerit, auferes et uteris.

You place eight ounces of mature myrtle berries_dried in the shade and then crushed-in a cloth and suspend it in wine; cover the jar and [†linabis†], and when it has been like this for several days, take it out and use it.

The form linabis, transmitted in the majority of MSS (DPKJLGM), does not exist in Latin; lines is transmitted in S. The issue with lines, as well as with Schmitt's conjecture oblines (printed in his Teubner (1898)) and the unattributed conjecture linibis, ${ }^{10)}$ is that in no other description of the process of making myrtle-wine in Palladius $(2.18,3.27,11.14 .5)$, or the Geoponika $(7.20),{ }^{11)}$ is there any mention made of sealing the jar. Columella offers three recipes for the manufacture of myrtle wine (12.38): the first (1-4) concerns itself with wine made from black myrtle berries, the second with that made from white berries (5-6), and the third from a mixture of the two (7-8). In the second recipe, the juice of white myrtle berries is to be added to Attic honey which has been boiled a number of times. Columella makes it quite clear that the berries are not to be placed in the wine, but that it is their sucus which is to be mixed with the preparation (6), and that this is then to be sealed in a jar ([sucum] in lagunculum diffusum oblinito). In the first recipe, the crushed black berries are to be mixed with the must of the grapes of an aged Aminnean vine; after a lengthy process of preparation, the wine is to be purified (purgatur (4)) and covered with a lid so that nothing falls in (operculum... superponitur, ne quid eo decidat (4)). Following seven days of resting and another purification, the wine is to be poured into amphorae which are described as bene picatae et bene olidae (4); there is no mention made of sealing the vessel. The third recipe offered by Columella has the juice of the mixed

\footnotetext{
10) Rodgers 1975a, ad loc. attributes it to edd.

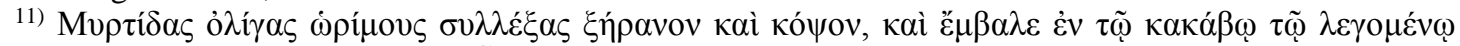

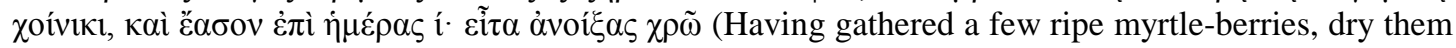
and pound them; put them into a pot called a $\chi 0 \tilde{v}\urcorner \xi$, and leave them there for nine days. Thereafter, open the container [which was, one might suppose, covered and not sealed] and use it.).
} 
berries passed through a linen bag, and then stored up in lagunculis bene picatis, without the addition of any preservative (7); again, no sealing of the container is mentioned, even though we are explicitly told that this liquid is less enduring than the others (hic liquor non tam est durabilis (7)). Columella suggests that one may also consider reducing part of the wine (again to be stored in picatis lagunculis without sealing), and that, in so doing, it lasts longer (diutius); when this further treatment is not undertaken, however, he notes that the wine may remain unsullied for two years (possit innoxium durare biennio (8)).

Returning to Palladius' text, it is clear that the first of the recipes which he offers, although not exactly the same, is closest to the first of Columella's three recipes (some aspects of the third are also visible in it): ${ }^{12)}$ myrtle berries which have been dried out and crushed are to steep in wine (in the case of Palladius' text, they are to do so from within a linen cloth (3.31.1), for Columella, as we have seen, they are placed directly into the wine); ${ }^{13)}$ both authors suggest that the container be covered, and that a period of time elapse before usage. Given the proximity of Palladius' recipes to the first (and third) of Columella's, it does not seem unreasonable to suppose that he would not have recommended the sealing of a jar for the storage of myrtle wine as Columella does in his second recipe; of the many flavoured wines for which Palladius provides a recipe, it is only pomegranate (4.10.10), rose (11.15), and honey wine (11.16) that must be sealed. ${ }^{14)}$ The detail that appears to be missing from the Palladian account of producing myrtle wine is that the vessels in which it is to be

\footnotetext{
${ }^{12)}$ It seems clear that different sources were used by Columella and Palladius, or that one or other of them may have confused aspects of the same one, but this ought not to negate a comparison of the two: the quantities of myrtle berries to be used may differ, but there is enough of a similarity between the rest of the descriptions of the process of manufacture that this ought not to be too problematic.

13) A similar recipe to this is offered as an alternative by Palladius at 3.31.2: [bacas] uino miscent.

14) There are a number of instances $(11.14 .5,11.14 .6,11.14 .10,11.14 .16)$ at which Palladius also recommends the sealing of a jar, but none of these refers to the manufacture of a particular sort of flavoured wine, but to the seasoning and care of a completed wine which is, for example, too sweet, too sour, red as opposed to white, \&c.
} 
stored should be pitched. All of the vessels in which wine is to be manufactured or stored should, in fact, be pitched according to both Columella and Palladius. ${ }^{15)}$ The pitching of a vessel must (of course) occur prior to any wine being put into it. If we accept that a mention of pitching is necessary here, a future tense is impossible, and what we really need is a perfect participle agreeing with uas. The corruption of a past participial form to a future form does not require a very great change, and considering the pressure from the future verbs cooperies and auferes surrounding this crux, it is unsurprising that it might have occurred. The verb which Columella uses to mean 'coat in pitch' is pico: this verb is used of vessels other than a laguncula, notably by Varro (r. 1.54.2: in amphoram picatam) and Cato (agr. 106: in uas picatum). If we imagine that Palladius wrote picatum, it would not be too difficult to see how picatum might have changed to picabis because of the nearby future forms; from there it is a straightforward corruption to the transmitted linabis under the influence of the preceding linteo. As an alternative to uas picatum, we might consider ceratum, assuming the same pattern of corruption; Columella describes the process of applying wax to a dolium used for storing oil (12.52: tum considerant numquid ceram nouam dolia desiderent; nam fere sexta quaque oliuitate cerari oportere antiqui dixerunt), but then goes on to explain that he thinks this rather outmoded. Pliny also speaks of waxed jars being used for wine, but counsels against it, as it causes the wine to sour (nat. 14.128: nam ceram accipientibus uasis conpertum uina acescere); this advice occurs in a lengthier passage discussing the best sorts of pitch to use in lining vessels (14.127-30), and so we would do better to read picatum than ceratum. One issue that should be raised regarding this emendation is the oddity of ac, now coupling the

\footnotetext{
15) Columella: dolia quoque et seriae ceteraque uasa ante quadragesimum uindemiae diem picanda sunt (12.18.5); Palladius: hoc mense locis tepidis maritimisque celebranda uindemia est, frigidis adparanda. in doliis picandis hic modus erit, ut dolium ducentorum congiorum duodecim libris picetur et deinde pro minoris aestimatione subducas (10.11.1).
} 
indicative cooperies and the participial picatum, given the Palladian tendency to use ac (atque) to join two equally weighted concepts (for example, 3.9.2, ualidas atque frondosas; 3.17.8, incidi atque transferri); though Palladius also uses it simply to add a further detail or instruction (for example, [bouum] si nimia fuerit asperitas, uno die ac nocte inter uincula mitigentur atque ieiunia (4.12)), where et might be expected. ${ }^{16)}$ This issue may be resolved by deleting ac, supposing that it was inserted by a scribe whose paradosis had two indicative verbs asyndetically coordinated after the corruption of the perfect participle had taken place. We should read et uas cooperies picatum. ${ }^{17)}$

\section{$\underline{6.10}$}

Hoc mense incipiunt augeri examina et in extremis fauorum partibus maiores creantur apiculae. quas aliqui reges putant, sed Graeci eos oestros appellant et necari iubent, quia requiem concutiunt quiescentis examinis.

In this month the colonies begin to grow, and in the farthest parts of hives larger bees are born. Some think these are the kings (sc. 'queens'), but the Greeks call them oí $\sigma \tau \rho o$ and order that they are killed, since they disturb the peace of the swarm at rest.

That we want oestros here is undisputed, though, I would suggest that eos should be omitted as it is in the MS J. Most manuscripts read eos eostros, which suggests that, in the course of J's transmission a haplography has taken place, leaving just the corrupt noun. It seems likely, however, that eos was originally written as a gloss to complete the sense after appellant (particularly in the light of the change of gender from the relative quas, with which oestros 'agrees', to this masculine noun). This would easily explain its introduction into the text. Svennung, however, suggests

\footnotetext{
16) Svennung 1935, 488.

17) One might be concerned on account of the separation of the noun from its participle by the finite verb cooperies here, though Palladius' word order is generally “etwas frei” (Svennung 1935, 494 n. 5; see also 549-50), and there are other instances of such a separation of a noun and its adjective by a finite verb in Palladius: aer oleas tepidus iuuat et uentis mediocribus sine ui et horrore perflabilis (1.6.20); (and of a participle from the noun which it describes) ut corrigas, si agrum conpares uitiis talibus occupatum (1.7.2).
} 
that the presence of eos in Palladius' text may have caused a copyist to read eostros for the correct oestros, leading to Isidore mistakenly quoting this passage with the word costros (orig. 12.8.3). ${ }^{18)}$ This may well be what did happen, but it is not much less plausible to imagine the change from the rare oestros to the otherwise unattested costros without the corrupting influence of the demonstrative pronoun: Rodgers has drawn attention to the unreliability of Isidore's text in establishing that of Palladius, and notes that “Isidore's costros gets us no closer to the original than Palladius' own manuscript tradition”. ${ }^{19)}$ Columella, on whom Palladius draws in this passage does not use a demonstrative either, though he might have done. ${ }^{20)}$ We should omit eos. ${ }^{21)}$

\section{1}

Hoc mense area paranda est ad trituram.... aliqui mundatis areis aquas spargunt et minuta ibi pecora diu spatiari ac proculcare conpellunt.

The MSS are divided between aquas (M), aquam (GS), and aqua (DPKJL). ${ }^{22)}$

The issue appears to be whether one sprinkles with water in the singular or plural in idiomatic Latin. A PHI search on aqu spar produced a clear result: in prose, water is always sprinkled in the singular, whether it is the object of spargo or conspargo as the substance sprinkled (spargentes aquam, Plin. nat. 18.361), or an instrumental ablative

\footnotetext{
18) Svennung 1935, 556; we might add that eos may have been added as a gloss prior to the text reaching Isidore, thereby bringing about the corruption to eostros as Svennung posits.

${ }^{19)}$ Rodgers 1975b, 71; it has also been suggested (Svennung 1935, 556) that Isidore may have altered the spelling of oestros/eostros to costros so as to enhance his explanation of Latin's derivation of castra from Greek: if this is the case, I see no reason why eos needs to have been present to cause the corruption to eostros in the first place, as a wilful alteration is as straightforward from oestros as from eostros. Either way, I think this unlikely, and overcomplicating.

20) eodemque tempore progenerantur in extremis partibus fauorum amplioris magnitudinis quam sunt

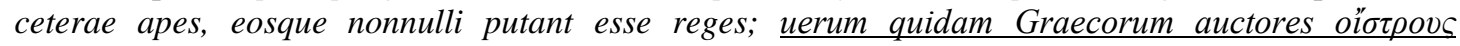
appellant, ab eo quod exagitent nec patiantur examina conquiescere; itaque praecipiunt eos enecari (9.14.4).

21) It should briefly be noted that the punctuation adopted by Rodgers (see above) tolerates this emendation, though Schmitt's colon does not (quas aliqui reges putant: sed Graeci eos oestros appellant et necari iubent).

${ }^{22)}$ Schneider's conjecture fabam is rightly dismissed by Rodgers (1975b), 127, who notes that 'water is what we want here'.
} 
of the thing with which something else is sprinkled (aquā spargunt, Plin. nat. 10.92) ${ }^{23)}$ Only in poetry are there any examples of aqua occurring in the accusative or ablative plural with spargo. ${ }^{24)}$ Svennung argues for the singular ablative aqua found in DPKJL, saying that it is in the best MSS, and that it could easily be corrupted into the other forms transmitted (aquam or aquas). ${ }^{25)}$ Whilst this is true, and the transmitted ablative is appropriately singular, there is a basic issue at stake: when (con)spargo has an accusative object of the thing on to which the water is being scattered, aqua is found to be in the ablative (farinam aquā sparsit, Sen. ep. 90.23), whilst if the thing being bespattered is in the ablative, then aqua is in the accusative (qui aquam equis spargunt, Ulp. dig. 3.2.4). Although the PHI search is not exhaustive, it seems to be the case that (con)spargo takes only one accusative at a time when aqua is being sprinkled: either the water is the accusative object of the verb, or whatever is sprinkled by the water is, but not both. Since we have a sure ablative in mundatis areis, it seems likely that GS's reading of aquam is the correct one, since we want a singular accusative form.

\section{$\underline{12.16}$}

Hoc mense locis siccis, calidis et apricis maiores arbores transferemus truncatas ramis, inlaesis radicibus, multo stercore et rigationibus adiuuandas.

In this month, in dry, warm, and sunny places, we shall transplant bigger trees, stripped as to their branches, and with unharmed roots; they need to be supported with a lot of manure and water.

The sense of truncatas ramis, inlaesis radicibus should clearly be that larger trees should be moved once their branches have been stripped, and with the roots

\footnotetext{
23) These were the prose results of the PHI search (I omit several examples from Columella and Pliny, all of which follow the same idiomatic pattern): Cato, aquā spargito (agr. 157.13); Col., conspargitur aquā glaeba (2.2.18), aquā consparsi (6.3.8), aquā conspargendae (6.5.2), \&c.; Plin., quae salsā aquā sparsa (nat. 18.87), spargentes aquam (nat. 18.361), \&c.; Larg., consparguntur aquā pluuiā (159); Sen., farinam aquā sparsit (ep. 90.23); Serv., spargendo aquam imitare pluuiam (g. 4.230).

${ }^{24)}$ The results of the PHI search for poetry were as follows: Hor., spargens...aquas (epod. 5.26); Ov., spargit...aquis (fast. 6.157), spargitur...aquā (fast. 2.113), \&c.; Verg., spargit aquā (A. 6.636); Juv., portabit aquas, ut spargat (6.528).

25) Svennung 1935, 632.
} 
unharmed. The majority of manuscripts transmit truncatas (DPKLGSM), whilst J has the impossible truncatos; editors have suggested truncatis (so Schmitt prints), which also appears in a twelfth-century MS of the text (Merton College, Oxford MS 311 (H.3.11)). ${ }^{26)}$ This may be the result of a simple attraction to the ending of ramis by a scribe who had truncatas before him in one of the uetustiores, though we cannot rule out the possibility that he might, of his own volition, have corrected it to truncatis. The reading accepted by Rodgers (arbores... truncatas ramis) may be explained easily enough as a perfect participle in agreement with arbores followed by an ablative of separation, such as Palladius uses at 3.17.8 (plantam persici... spoliatam ramis). ${ }^{27}$ ) trunco is used with such an ablative in the description of Baucis' preparation of a cabbage: truncat holus foliis (Ov. met. 8.647). The most closely related passage to the Palladian text in lexical terms is the rather peculiar and unparalleled Columellan periphrasis cum... arbor sine ramis truncata est (5.6.25). It seems to me that the oddity of this passage may be eliminated if we consider that sine ramis may, in fact, be a gloss on arbor truncata est which has intruded into the main body of the text; the words sine ramis should be deleted as an interpolation. If this were accepted, the Columellan text would be paralleled by Suetonius' ablative absolute, truncatisque arboribus (Cal. 45.1), where once again the thing of which the tree is stripped is not mentioned: a Roman, it seems, would have written arborem truncat, but would not have mentioned the branches - the obvious thing which one strips from a tree. One might thus wonder about the deletion of ramis in Palladius' text too, though this would have the disadvantage of creating an imbalance between the resultant participial phrases, truncatas and inlaesis radicibus. In the light of this, although ramis truncari is unparalleled, it seems best here to read arbores

\footnotetext{
${ }^{26)}$ v. Rodgers 1975b, 168.

27) I find Rodgers' musing on whether inlaesas radicibus ought to be read here doubtful.
} 
transferemus truncatis ramis, understanding truncatis ramis as an ablative absolute.

In this way the textual issue is resolved, and the sense becomes 'we shall relocate the trees when their branches have been removed'; thereby maintaining the balance with inlaesis radicibus. $^{28)}$

Bibliography:

Cam, M.-T. 2001. Cetius Faventinus: Abrégé d’Architecture Privée (Paris)

Fitch, J.G. 2013. Palladius: The Work of Farming (Totnes)

Martin, R. 1976. Palladius: Traité d'Agriculture, Tome I (Paris)

Moure Casas, A.M. 1980. Palladius, Liber Primus: Tradición manuscrita y edición critica (Madrid) (with review by Corsetti, P.-P. 1985, in REL 63: 297-9)

Rodgers, R.H. 1975a. Palladius: Opus Agriculturae \&c. (Leipzig)

Rodgers, R.H. 1975b. An Introduction to Palladius (London)

Rodgers, R.H. 2010. L. Iuni Columellae Res Rustica \&c. (Oxford)

Rose, V. \& Müller-Strübling, H. 1867. Vitruuii de Architectura libri decem (Leipzig)

Schmitt, J.C. 1898. Palladii Rutilii Tauri Aemiliani uiri inlustris opus agriculturae (Leipzig)

Svennung, J. 1935. Untersuchungen zu Palladius und zur lateinischen Fach- und Volkssprache (Uppsala)

Tristan E. Franklinos

Wadham College, Oxford, OX1 3PN, United Kingdom

tristan.franklinos@classics.ox.ac.uk

28) My thanks to the anonymous reader whose attentive reading and suggestions removed several infelicities, and to Dr S. J. Heyworth for his acute eye, insightful comments, unstinting support, and friendly discussion. 